\title{
Diagnosis Infeksi Dengue di Era Pandemi COVID-19
}

Mulya Rahma Karyanti, Pinka Nurashri Setyati

Departemen Ilmu Kesehatan Anak Rumah Sakit Dr. Cipto Mangunkusumo Fakultas Kedokteran Universitas Indonesia, Jakarta

Latar belakang. Penegakan diagnosis infeksi dengue menjadi tantangan di era pandemik COVID-19. Kasus misdiagnosis dan ko-infeksi antara infeksi dengue dengan COVID-19 telah dilaporkan karena adanya kemiripan gejala klinis maupun pemeriksaan laboratorium. Keterlambatan atau kesalahan penegakan diagnosis dapat menimbulkan kerugian pada pasien, maupun petugas kesehatan.

Tujuan. Mendapatkan strategi penegakan diagnosis infeksi dengue yang cepat dan tepat pada era pandemi COVID-19.

Metode. Penelusuran artikel melalui database ilmiah.

Hasil. Infeksi dengue dan COVID-19 memiliki perbedaan patofisiologi dan target organ. Kedua penyakit tersebut memiliki ciri khas yang sama yaitu terjadinya disfungsi endotel. Terdapat perbedaan karakteristik demam dimana infeksi dengue dengan saddleback fever dan COVID-19 prolonged fever. Gejala saluran pernapasan lebih umum ditemui pada pasien COVID-19 (76\%) dibandingkan pada infeksi dengue (21,5\%). Sementara itu, gejala gastrointestinal berupa nyeri abdomen, muntah persisten merupakan gejala warning signs penting pada infeksi dengue, sedangkan diare dapat terjadi pada COVID-19. Manifestasi perdarahan pada infeksi dengue terutama dapat berupa petekie, epistaksis, gusi berdarah atau perdarahan saluran cerna, tetapi pada COVID-19 tidak terjadi. Pada infeksi dengue pada fase awal demam dapat timbul muka kemerahan (flushing) dan fase penyembuhan muncul rash konvalesen yang dapat disertai rasa gatal pada ektremitas, sementara ruam eritematosa adalah temuan pada COVID-19. Pemeriksaan laboratorium yang cepat, mudah, praktis dan tersedia dalam praktek untuk konfirmasi infeksi dengue dilakukan pemeriksaan antigen NS1 dengue, sedangkan konfirmasi COVID-19 dilakukan pemeriksaan PCR SARS-CoV-2 dari swab naso dan orofaring.

Kesimpulan. Infeksi dengue dan COVID-19 memiliki gejala klinis dan temuan laboratorium yang serupa. Diagnosis infeksi dengue pada era pandemi COVID-19 dapat dikonfirmasi dengan antigen NS1 bersamaan dengan PCR SARS-CoV-2.Sari Pediatri 2021;23(2):136-42

Kata kunci: infeksi dengue, COVID-19, diagnosis

\section{Diagnosis of Dengue Infection in the Era of the COVID-19 Pandemic}

Mulya Rahma Karyanti, Pinka Nurashri Setyati

Background. To diagnose dengue infection is a challenge during the COVID-19 pandemic. Misdiagnosed and co-infection cases between dengue infection and COVID-19 have been reported, due to similar clinical manifestations and laboratory tests. A delay in making diagnosis can further harm not only the patients but also health workers.

Objective. To obtain a strategy to diagnose dengue infection in timely manner during the COVID-19 pandemic.

Method: Online scientific databases for scientific articles.

Results. Dengue infection and COVID-19 have different pathophysiology and target organs. Both diseases share the same hallmark which is endothelial dysfunction. There are differences in the characteristics of fever where dengue infection presented with saddleback fever while COVID-19 with prolonged fever. Respiratory tract symptoms are more common in COVID-19 patients (76\%) than in dengue infection $(21.5 \%)$. Meanwhile, gastrointestinal symptoms such abdominal pain, persistent vomiting are important warning signs in dengue infection, whereas diarrhea are common in COVID-19. Bleeding manifestations in dengue infection can be petechiae, epistaxis, gum bleeding or gastrointestinal bleeding, but not in COVID-19. In the early phase of fever, flushing may occur and in the convalescence phase, rash convalescence sometimes with itchy may occur in the extremities, while an erythematous rash is the common finding in COVID-19. A rapid, easy, practical and available laboratory examination in clinical settings for dengue infection confirmation is performing NS1 dengue antigen test, whereas confirmation for COVID-19 is PCR SARS-CoV-2 from naso and oropharyangeal swab.

Conclusion. Dengue infection and COVID-19 share some similar clinical manifestations and laboratory findings. The diagnosis of dengue infection in the era of the COVID-19 pandemic can be confirmed with the NS1 dengue antigen along with SARS-CoV-2 PCR. Sari Pediatri 2021;23(2):136-42

Keywords: dengue infection, COVID-19, diagnosis

Alamat korespondensi: Mulya Rahma Karyanti. Departemen Ilmu Kesehatan Anak Rumah Sakit Dr. Cipto Mangunkusumo Fakultas Kedokteran Universitas Indonesia, Jakarta.Email: karyanti@ikafkui.net 
I ndonesia merupakan salah satu negara tropis yang masih endemis dengue. Di era pandemi COVID-19, menghadapi kasus infeksi dengue menjadi tantangan. Kasus DBD pada tahun 2020 mencapai 95.893 kasus. ${ }^{1,2}$ Kasus COVID-19 di Indonesia, per 13 Februari 2021, terkonfirmasi telah mencapai $1.210 .703 .{ }^{3}$

Kasus misdiagnosis dan ko-infeksi antara infeksi dengue dengan COVID-19 telah banyak dilaporkan karena adanya kemiripan antara gejala klinis yang muncul pada kedua penyakit ini, yaitu demam, batuk, diare dan munculnya ruam kemerahan pada kulit. ${ }^{4}$ Beberapa penelitian menyebutkan adanya kemungkinan terjadinya reaksi silang pada pemeriksaan serologi antibodi dari virus dengue dan SARS-CoV-2.5-7

Keterlambatan atau kesalahan penegakan diagnosis dapat mengakibatkan kesalahan pemberian tatalaksana sehingga menyebabkan dampak yang buruk pada pasien, maupun petugas kesehatan jika tidak menggunakan alat pelindung diri (APD) yang sesuai. Diperlukan strategi uji diagnostik yang memiliki spesifisitas tinggi untuk penegakan diagnosis infeksi dengue dengan cepat dan tepat, terutama pada era pandemi COVID-19.

\section{Metode}

Penulis melakukan penelusuran artikel melalui database ilmiah online seperti PubMed, Mendeley, dan ProQuest dengan kurun waktu terbit tahun 2020-2021. Artikel yang paling relevan dipilih menggunakan kata kunci "dengue", "dengue virus", "DENV", "dengue fever", "dengue haemmoraghic fever" dalam kombinasi dari "COVID-19", "corona virus", "SARS-CoV-2" dan dalam kombinasi "diagnosis", "clinical manifestasion", "laboratory findings", dan "serology."

Penapisan artikel ilmiah dilakukan dengan kriteria inklusi: tanggal publikasi 1 tahun lalu, bahasa Inggris, dan dalam bentuk teks lengkap. Artikel yang diperoleh 649 dari database ilmiah daring kemudian dikurangi menjadi 17 artikel setelah menyaring dari judul dan abstrak, dan membaca teks lengkap.

\section{Epidemiologi}

Pada tahun 2019, kasus DBD adalah 137.761 dan tahun 2020 mencapai 95.893 kasus. ${ }^{1,2}$ Proporsi kasus
DBD tahun 2020 per golongan umur pada kelompok usia $<1$ tahun sebesar 3,13\%, usia $1-4$ tahun $14,88 \%$ dan usia 5-14 tahun 33,97\%. ${ }^{2}$ Bersamaan dengan itu, kasus COVID-19 di Indonesia yang terkonfirmasi telah mencapai 1,123,105 per 5 Februari 2021. ${ }^{3}$ Angka kasus terkonfirmasi COVID-19 pada anak di Indonesia pada kelompok usia 0-5 tahun mencapai 2,8\% dan kelompok usia 6-18 tahun sebesar 9,1\%. Angka kematian pada anak yang terinfeksi COVID-19 adalah 2,3\%. ${ }^{3}$

Pada 11 Maret 2020, WHO menetapkan COVID-19 sebagai pandemi. Virus ini pertama kali sampai di Indonesia pada Maret 2020 pada pasien dengan riwayat kontak dengan orang yang memiliki riwayat perjalanan ke negara dengan kasus positif COVID-19. Dalam waktu bersamaan dengan pandemi COVID-19, kasus infeksi dengue di Indonesia mulai meningkat dan memuncak di bulan April-Mei 2020 yang terjadi setiap tahunnya pada musim hujan.

\section{Perjalanan penyakit dengue dan $\mathrm{CO}$ - VID-19}

Virus dengue ditularkan melalui gigitan nyamuk Aedes aegypty betina dan memiliki masa inkubasi 5-7 hari. Perjalanan penyakit infeksi dengue berlangsung selama 7 hari, yang dibagi 3 fase, yaitu fase demam (hari ke-1 sampai ke-3), fase kritis (hari ke-3 sampai ke-6) dan fase penyembuhan (hari ke-6-7). Infeksi dengue memiliki spektrum klinis yang luas dari asimptomatik, ringan sampai berat. Tanda dan gejala pada infeksi dengue adalah demam yang timbul mendadak tinggi (dapat mencapai $40^{\circ} \mathrm{C}$ ), terus-menerus, kadang bifasik, serta berlangsung selama 2-7 hari. ${ }^{8}$ Demam disertai dengan gejala lain yang sering ditemukan, seperti muka kemerahan (facial flushing), nyeri kepala, nyeri retroorbital, anoreksia, mialgia, artralgia dan manifestasi perdarahan seperti petekie, epistaksis, perdarahan gusi dan perdarahan saluran cerna. Gejala lain yang mungkin dijumpai adalah nyeri ulu hati, mual, muntah, nyeri di daerah subkostal kanan atau nyeri abdomen difus, kadang disertai batuk atau diare. ${ }^{8}$

Pada infeksi dengue, pada fase kritis (antara hari ke-3 sampai ke-6) terjadi kebocoran vaskular sehingga dapat terjadi syok hipovolemik jika tidak diberi tatalaksana cairan yang adekuat dan dapat mengakibatkan kematian. Pada fase kritis dengue beberapa sitokin yang terlibat adalah GM-CSF, IFN- $\gamma$, 
IL-10, IL-15, IL-8, MCP-1, IL-6, MIP-1 $\beta$, dan TNF- $\alpha$ juga meningkat. Selain itu, empat sitokin lain, yaitu IFN- $\gamma$, GM-CSF, IL-10, dan MIP-1 $\beta$, berkorelasi secara signifikan dengan terjadinya kebocoran vaskular yang dapat mengakibatkan syok hipovolemik dan dapat berfungsi sebagai prediktor potensial. ${ }^{4}$

Virus SARS- CoV-2 menular melalui droplets, kontak, maupun airborne (jika ada tindakan aerosol generating procedure), dengan masa inkubasi berkisar 7 hari. Berdasarkan gejala COVID- 19, manifestasi klinis dapat dibagi menjadi tiga fase; fase permulaan, akselerasi, dan fase pemulihan. Gejala klinis COVID-19 dapat bervariasi, mulai dari asimptomatis, ringan, sedang sampai berat. ${ }^{9}$ Gejala infeksi COVID-19 didahului demam, anosmia, ageusia diikuti gejala saluran napas atas, batuk, nyeri tenggorokan, pilek, fatigue, dan mialgia. ${ }^{9}$ Gejala dyspnea mulai timbul pada rerata median hari ke-5 sampai 8, dan acute respiratory distress syndrome (ARDS) terjadi pada rerata median hari ke-8 sampai 12. Selain itu dapat muncul gejala saluran pencernaan, seperti mual, muntah, nyeri perut, diare, atau gejala non-respiratori lainnya. Pada anak dapat timbul gejala yang terkadang luput dari perhatian tenaga medis, seperti timbulnya ruam pada kulit. ${ }^{9}$

Patogenesis dari virus SARS- CoV-2 setelah virus masuk ke dalam tubuh pejamu, angiotensin-converting enzyme 2 (ACE2) dapat membawa virus ke jaringan paru, terutama pneumosit tipe 2. Pneumosit yang telah terinfeksi kemudian mengaktivasi sistem imun bawaan yang memiliki mediator inflamasi seperti monosit, makrofag, dan toll-like receptor yang akan memproduksi berbagai sitokin inflamasi dan kemudian akan menstimulasi sistem imun adaptif. ${ }^{4}$

Sitokin inflamasi tersebut adalah IL-2, IL-7, IL10, tumor necrosis factor (TNF), granulocyte-colony stimulating factor (G-CSF), interferon gamma-induced protein 10 (IP-10; CXCL10), MCP-1. (CCL2), dan MIP-1A (CCL3), yang ditemukan meningkat pada pasien yang dirawat di unit perawatan intensif (ICU) dibandingkan dengan pasien non-ICU. Sitokin lain yang baru-baru ini ditemukan pada COVID-19 adalah IL-1 $\beta$, IL-1ra, IL-2R, IL-6, IL-8 (CXCL8), IL-17, interferon (IFN)- $\gamma$, dan granulocyte macrophage colonystimulating factor (GM-CSF). ${ }^{4}$

Pada studi lain yang dilakukan oleh Dayarathna $\mathrm{dkk}^{10}$ pada pasien COVID-19 dengan gejala berat dan DBD/ dengue berat memiliki kadar IL-6, IL-10 dan MIP3 $\alpha$ yang secara signifikan lebih tinggi daripada pasien dengan gejala ringan. Kadar IL-10, IL-6, MIP-
$3 \alpha$ dan kadar CD40-L meningkat secara signifikan pada pasien dengan COVID-19 sedang hingga berat. Sebaliknya, kadar sitokin tersebut tidak berubah pada penderita DBD selama fase demam dan kritis. Pasien dengan DBD memiliki kadar IL-10 25 kali lipat lebih tinggi daripada COVID-19. ${ }^{10}$ Sementara itu, terdapat peningkatan kadar IL-6 sebesar 11 kali lipat pada pasien dengan COVID-19. ${ }^{10}$ Sebuah studi dari $\mathrm{Ng} \mathrm{dkk^{11 }}$ yang juga membandingkan profil sitokin antara pasien yang DBD dengan COVID-19 menemukan peningkatan kadar IL-1 $\alpha$ pada pasien DBD dan dan tingkat IP-10 yang lebih rendah dibandingkan dengan COVID-19.

Penyakit COVID-19 dan DBD memiliki beberapa perbedaan penting terkait patofisiologi dan target organ. Pada sisi lain, kedua penyakit tersebut memiliki ciri khas yang sama, yaitu terjadinya disfungsi endotel. ${ }^{4}$ Oleh karena ada persamaan tersebut, dapat menjelaskan beberapa kesamaan manifestasi klinis yang ditemukan pada kedua penyakit tersebut.

\section{Persamaan gejala klinis antara dengue dengan COVID-19}

\section{Demam}

Demam merupakan keluhan utama yang paling banyak ditemukan pada pasien DBD dan COVID-19. Dalam dua studi kohort yang menggunakan 515 dan 154 subjek dengan DBD, semua subjek mengalami demam. ${ }^{12,13}$ Sebagai perbandingan pada tiga studi kohort pada pasien COVID-19 dengan gejala demam, didapatkan hasil masing-masing adalah $92,2 \%, 98 \%$, dan $98,6 \% .{ }^{14-}$ ${ }^{16}$ Perbedaan demam muncul pada karakteristik demam. Pada pasien infeksi dengue karakteristiknya adalah saddleback fever. Namun dalam kasus COVID-19, karakteristik demam adalah prolonged fever. ${ }^{11}$

\section{Gejala saluran pernafasan}

Pada sebuah studi didapatkan pasien dengue fase awal yang mengeluhkan batuk sebanyak 21,5\%. ${ }^{17}$ Dalam penelitian kohort dari 100 pasien dengue insiden ARDS, pulmonary hemorrhage, pneumonitis bilateral, dan efusi pleura pada kelompok DBD, berturut-turut adalah 53,3\%; 6,6\%; 6,6\% dan $100 \% .{ }^{18}$ Berdasarkan penelitian tersebut, gambaran foto toraks ditemukan pada pasien DBD adalah efusi pleura sebesar 100\%.

Pada COVID-19 batuk merupakan gejala saluran pernapasan yang paling umum ditemui. Pasien 
COVID-19, menunjukkan gejala saluran pernafasan lebih tinggi yaitu sebesar $76 \%$, dan sering mengakibatkan kematian. ${ }^{9}$ Sementara itu, gambaran yang ditemukan pada pasien COVID-19 pada CT-Scan Thorax adalah ditemukannya gambaran 'Ground glass opacity' pada kedua lapang paru..$^{14,16}$

\section{Gejala gastrointestinal dan hati}

Gejala gastrointestinal (GI), seperti diare, sakit perut, muntah, dan mual sering terjadi pada infeksi dengue dan COVID-19. Sebesar $6 \%$ pasien DBD mengalami diare. Akan tetapi, diare sebagai satu-satunya gejala klinis pada infeksi dengue belum pernah sebelumnya dilaporkan. Sebaliknya, terdapat studi yang melaporkan sebanyak 3\% pasien COVID-19 yang hanya mengeluhkan demam dan gejala GI. ${ }^{15}$

Muntah adalah gejala yang umum dijumpai pada infeksi dengue dan muncul sebesar 30\%-58\% pada pasien. ${ }^{4}$ Nyeri perut ditemui pada infeksi dengue sebesar 17\%-25\% pasien. ${ }^{12}$ Pada COVID-19, gejala GI seperti muntah muncul hanya pada $4-5 \%$ pasien dan nyeri perut hanya sebesar $2 \% .{ }^{15,16}$ Gejala GI pada COVID-19 memiliki persentase yang relatif rendah, lain halnya dengan infeksi dengue. Gejala GI merupakan warning signs penting yang terjadi saat masuk fase kritis (setelah hari ke-3), saat memasuki fase syok hipovolemik. Warning signs pada infeksi dengue terdiri dari nyeri abdomen, muntah terus menerus, letargi, perdarahan mukosa, hepatomegali, akumulasi cairan, peningkatan hematokrit dan penurunan trombosit yang drastis. ${ }^{8}$

Gejala GI utama lainnya adalah peningkatan enzim hati. Pada infeksi dengue terjadi peningkatan SGOT lebih tinggi 3 kali lipat dari SGPT. ${ }^{12}$ Peningkatan SGOT dapat berasal dari lisis sel jantung, otot lurik, miosit, monosit atau eritrosit. Sementara peningkatan SGPT terutama berasal dari lisis sel hati. Adanya cidera terhadap jaringan non-hati oleh infeksi dengue yang sistemik dapat menyebabkan peningkatan SGOT yang lebih tinggi jika dibandingkan dengan peningkatan SGPT. ${ }^{19-21}$

Tiga penelitian deskriptif pada pasien COVID-19 menunjukkan terdapat $31-35 \%$, dan $24-28 \%$ pasien COVID-19 mengalami peningkatan kadar SGOT dan SGPT. ${ }^{14,15}$ Persentase peningkatan enzim hati pada pasien COVID-19 lebih didominasi peningkatan SGOT, persentase peningkatan SGOT memiliki rentang 63-97\% sementara peningkatan SGPT memiliki rentang yang lebih rendah pada angka $45-97 \% .^{4}$

\section{Gejala pada kulit}

Gejala kulit adalah keluhan lain yang dapat timbul pada kedua penyakit. Pada infeksi dengue, temuan pada fase awal penyakit adalah muka kemerahan (facial flushing) dan petekie. Pada periode penyembuhan muncul convalescent rash yang digambarkan sebagai "land of white in the sea of red" karena adanya permukaan kulit yang normal diantara petekie. ${ }^{4}$ Dalam satu penelitian yang terdiri dari 88 pasien COVID-19, 20,4\% di antaranya timbul kelainan pada kulit, dapat berupa ruam eritematosa, diikuti oleh urtikaria yang menyebar luas, dan satu pasien dengan keluhan timbul vesikel seperti cacar air. ${ }^{22}$

\section{Reaksi silang serologi antibodi}

Infeksi dengue dan COVID-19 memiliki beberapa manifestasi klinis dan hasil pemeriksaan laboratorium yang sama. Maka dari itu diperlukan tes diagnostik khusus untuk dapat mengonfirmasi diagnosis. Sebuah studi oleh Spinicci $\mathrm{dkk}^{5}$ menyelidiki potensi timbulnya reaksi silang antara infeksi dengue dengan COVID-19. Di antara 32 pasien yang positif COVID-19, tidak ada yang menunjukkan hasil pemeriksaan positif pada pemeriksaan DENV IgG/IgM. Di sisi lain, satu hasil positif palsu untuk COVID-19 muncul diantara 44 DENV-positif. Uji serologis untuk infeksi dengue diketahui dipengaruhi dari reaksi silang di daerah endemis virus Flavivirus, seperti Zika, Chikunguya atau virus Japanese Encephalitis. ${ }^{5}$ Risiko hasil positif palsu dapat dikurangi jika pemeriksaan antibodi IgM/IgG dengue dipadukan dengan uji tapis antigen NS1 dengue.

Dalam studi kohort lain, Lustig $\mathrm{dkk}^{6}$ menguji antibodi $\operatorname{IgG}$ dan IgM dengue. Hasil yang didapat adalah dari 12 pasien COVID-19 yang positif, hanya satu sampel yang menujukkan hasil IgG positif lemah dan tidak ada yang menunjukkan hasil IgM positif. Pada pemeriksaan ELISA dengue IgM dan IgG ditunjukkan hasil positif pada satu dan lima pasien dari 43 pasien COVID-19 dengan hasil antibodi IgG dan IgM dengue awal negatif. Hasil penelitian ini menunjukkan bahwa kesamaan struktur dari virus SARS-CoV-2 dan struktur protein virus dengue dapat menjelaskan adanya reaksi silang. ${ }^{6}$

\section{Penegakan diagnosis infeksi dengue}

Pemeriksaan antigen NS1 dengue dan ELISA NS1 cukup menjanjikan untuk penegakan diagnosis infeksi dengue, terutama apabila pasien datang pada fase 
Tabel 1. Perbedaan infeksi dengue dan COVID-19,9

\begin{tabular}{|c|c|c|}
\hline & Infeksi dengue & COVID-19 \\
\hline $\begin{array}{l}\text { Transmisi } \\
\text { penularan }\end{array}$ & Nyamuk Aedes Aegypty & Droplet/kontak/airborn (aerosol generating procedure) \\
\hline Masa inkubasi & 7 hari & 5-6 hari \\
\hline Gejala & $\begin{array}{l}\text { - } \text { Demam tinggi mendadak } \\
\text { - Muntah-muntah } \\
\text { - Mual } \\
\text { - Sakit kepala } \\
\text { - Lemas } \\
\text { - Rasa sakit yang muncul di belakang mata } \\
\text { - Nyeri pada otot dan persendian tulang } \\
\text { - Sakit perut } \\
\text { - Perdarahan kulit berupa bintik-bintik merah, } \\
\quad \text { mimisan, gusi berdarah, memar, muntah darah } \\
\text { dan BAB berdarah }\end{array}$ & $\begin{array}{l}\text { - Demam } \\
\text { - Batuk } \\
\text { - Pilek atau hidung berlendir } \\
\text { - Sakit tenggorokan } \\
\text { - Sesak napas } \\
\text { - Anosmia } \\
\text { - Ageusia } \\
\text { - Diare }\end{array}$ \\
\hline Musim & $\begin{array}{l}\text { Setelah musim hujan, puncak kasus dengue bulan } \\
\text { April-Mei setiap tahun }\end{array}$ & Sejak pandemi bulan Februari 2020 \\
\hline Masa kritis & $\begin{array}{l}\text { Demam hari ke-3 sampai ke-6 (fase kritis), terjadi } \\
\text { kebocoran vaskular yang mengakibatkan syok } \\
\text { hipovolemik sampai kematian }\end{array}$ & $\begin{array}{l}\text { Demam hari ke-5 sp } 8 \text { dapat dispneu, } \\
\text { Demam hari ke- } 8 \text { sp } 12 \text { terjadi ARDS Bahaya } \\
\text { terjadi pneumonia yang mengakibatkan sesak napas } \\
\text { bertambah sampai kematian }\end{array}$ \\
\hline $\begin{array}{l}\text { Tanda bahaya } \\
\text { (Warning } \\
\text { signs) }\end{array}$ & $\begin{array}{l}\text { Nyeri abdomen, muntah terus menerus, letargi, } \\
\text { perdarahan mukosa, hepatomegali, akumulasi } \\
\text { cairan, peningkatan hematokrit dan penurunan } \\
\text { trombosit drastis }\end{array}$ & $\begin{array}{l}\text { Sesak nafas bertambah, saturasi oksigen turun } \\
<92 \%\end{array}$ \\
\hline Pengobatan & Cairan & $\begin{array}{l}\text { Suportif } \\
\text { Antivirus remdesivir/favipiravir } \\
\text { Ceftriaxon/Azitromisin }\end{array}$ \\
\hline Pencegahan & $\begin{array}{l}\text { Membersihkan lingkungan } 3 \mathrm{M} \text { plus } \\
\text { Pelihara tanaman anti nyamuk }\end{array}$ & $\begin{array}{l}\text { Gunakan masker, jaga jarak }>1 \mathrm{~m} \text {, isolasi mandiri } \\
\text { jika sakit flu, cuci tangan dengan sabun dan air } \\
\text { mengalir/hand sanitizer, etika batuk }\end{array}$ \\
\hline Sasaran & Semua umur, terutama anak remaja & Semua umur, terutama yang berat usia lansia \\
\hline Kontak dekat & $\begin{array}{l}\text { Tertular melalui gigitan nyamuk Aedes Aegypty yang } \\
\text { mengandung virus dengue }\end{array}$ & Tertular jika ada kontak dekat terutama serumah \\
\hline $\begin{array}{l}\text { Pemeriksaan } \\
\text { darah }\end{array}$ & $\begin{array}{l}\text { Hari ke } 1-3 \text { demam } \\
\text { - Periksa Ag NS1 dengue } \\
\text { - Lekopenia } \\
\text { - Limositosis } \\
\text { Hari ke-4-6 demam } \\
\text { - Hematokrit naik } \\
\text { - Trombosit turun <100.000 } \\
\text { - Limfositosis } \\
\text { - CRP rendah } \\
\text { - Hari } \geq 5 \text { periksa IgG dan IgM dengue }\end{array}$ & $\begin{array}{l}\text { Swab naso/orofaring PCR COVID-19 } \\
\text { Leokopenia }<1500 / \mathrm{mm} 3 \\
\text { Limfositopenia } \\
\text { CRP meningkat } \\
\text { Netrofil limfosit ratio } \geq 3,13 \\
\text { LDH meningkat } \\
\text { D-dimer meningkat } \\
\text { Hari } \geq 7 \text { periksa Ig M COVID-19 }\end{array}$ \\
\hline $\begin{array}{l}\text { Perjalanan } \\
\text { penyakit }\end{array}$ & $\begin{array}{l}\text { Lama } 7 \text { hari } \\
\text { Hari ke- } 7 \text { masuk fase penyembuhan, ditandai pada } \\
\text { kaki dan tangan timbul ruam kemerahan dapat } \\
\text { disertai gatal }\end{array}$ & $\begin{array}{l}\text { Semakin hari sesak napas bertambah dengan } \\
\text { pneumonia yang tambah berat }\end{array}$ \\
\hline
\end{tabular}


awal. Sensitivitas dan spesifisitas antigen NS1 dengue masing-masing adalah 55,5\% dan $92 \%$. $^{7}$ Dalam studi oleh Solanke $\mathrm{dkk},{ }^{23}$ hasil positif antigen NS1 dengue pada hari 4-6 adalah 39,4\%, kemudian akan menurun menjadi $13,1 \%$ pada hari ke 79 . Namun, dalam kondisi terbatas, uji antigen NS1 dengue yang dilakukan secara tepat dapat menjadi kunci dalam mengonfirmasi diagnosis infeksi dengue karena tidak menunjukkan reaksi silang dengan Flavivirus lain. ${ }^{7}$ Tabel 1 menjelaskan perbedaan antara infeksi dengue dengan COVID-19 mulai dari transmisi, hingga perjalanan penyakit.

Diagnosis COVID-19 dikonfirmasi dengan pemeriksaan RT-PCR SARS-CoV-2 dari swab naso dan orofaring. Keterbatasan reagen dan sumber daya di beberapa daerah membuat metode ini tidak praktis untuk pengujian massal atau cepat, dan oleh karena itu uji serologis antigen SARS-CoV-2 dapat digunakan untuk diagnosis awal, sensitifitas dan spesifisitas bervariasi masing-masing mulai dari $9 \%-88.6 \%$ dan $88.9 \%-91.7 \% .^{24}$

Pada kondisi pengujian diagnostik molekuler untuk dengue tidak tersedia, maka direkomendasikan penggunaan antigen NS1 dan IgM/IgG RDT yang telah divalidasi. ${ }^{7}$ Deteksi IgM dan/atau titer IgG dengue yang tinggi tidak boleh dianggap sebagai kasus negatif COVID-19. Infeksi dengue sebelumnya dengan infeksi COVID-19 akut atau kasus koinfeksi dapat terjadi. Oleh karena itu, evaluasi untuk COVID-19 perlu dilakukan ketika antigen NS1 dengue atau RT-PCR menunjukkan hasil negatif. ${ }^{25,26}$

\section{Kesimpulan}

Kedua penyakit dengue dan COVID-19 memiliki gejala klinis dan temuan laboratorium yang serupa. Hasil pemeriksaan serologi antibodi IgM dan IgG untuk dengue dapat terjadi positif palsu, pada SARS-CoV-2, demikian juga sebaliknya karena terjadi reaksi silang. Diagnosis infeksi dengue pada era pandemi COVID-19 dapat dikonfirmasi dengan antigen NS1 dengue pada 5 hari pertama, sedangkan konfirmasi COVID-19 dengan PCR SARS-CoV-2 dari swab naso dan orofaring. Diagnosis yang salah atau tertunda dapat berakibat fatal dikarenakan tatalaksana kedua penyakit yang berbeda dan alat pelindung diri yang sesuai diperlukan bagi petugas kesehatan.

\section{Daftar pustaka}

1. Direktorat Jenderal Pencegahan dan Pengendalian Penyakit. Kasus demam berdarah dengue (DBD) menurut jenis kelamin dan provinsi di Indonesia tahun 2019. Dalam: Kementerian Kesehatan Republik Indonesia. Profil kesehatan Indonesia tahun 2019. Edisi pertama. Jakarta: Kemkes RI; 2019. h. 169.

2. Kementerian Kesehatan Republik Indonesia. Informasi singkat DBD 2020 [Internet]. Kemkes RI. 2020 [Diunduh pada 12 Januari 2021]. Didapat dari: https://sehatnegeriku.kemkes. go.id/bacalumum/20201203/2335899/data-kasus-terbaru-dbdindonesial.

3. Satuan Tugas Penanganan COVID-19. Peta sebaran Covid-19 [Internet]. 2021 [Diakses pada 5 Februari 2021]. Didapat dari: https://covid19.go.id/peta-sebaran-covid19.

4. Henrina J, Putra ICS, Lawrensia S, Handoyono QF, Cahyadi A. Coronavirus disease of 2019: A mimicker of dengue infection? SN Compr Clin Med 2020;2:1109-19.

5. Spinicci M, Bartoloni A, Mantella A, Zammarchi L, Rossolini GM, Antonelli A. Low risk of serological cross-reactivity between dengue and COVID-19. Mem Inst Oswaldo Cruz 2020;115:e200225.

6. Lustig Y, Keler S, Kolodny R, dkk. Potential antigenic crossreactivity between SARS-CoV-2 and dengue viruses. Clin Infect Dis 2020;14:ciaa1207.

7. Kembuan GJ. Dengue serology in Indonesian COVID-19 patients: coinfection or serological overlap? ID Cases 2020;22:e0927.

8. Kementerian Kesehatan Republik Indonesia. Pencegahan dan pengendalian demam berdarah dengue di Indonesia. Edisi pertama. Jakarta: Kemkes RI; 2017.

9. Perhimpunan Dokter Paru Indonesia, Perhimpunan Dokter Spesialis Kardiovaskular Indonesia, Perhimpunan Dokter Spesialis Penyakit Dalam Indonesia, Perhimpunan Dokter Anestesiologi dan Terapi Intensif Indonesia, Ikatan Dokter Anak Indonesia. Pedoman tatalaksana Covid-19 Edisi ke-3. Jakarta: PDPI, PERKI, PAPDI, PERDATIN, IDAI; 2020.

10. Dayarathna S, Jeewandara C, Gomes L, dkk. Similarities and differences between the 'cytokine storms' in acute dengue and COVID-19. Sci Rep 2020;10:1-12.

11. Ng DHL, Choy CY, Chan Y-H, dkk. Fever patterns, cytokine profiles, and outcomes in COVID-19. Open Forum Infect Dis 2020;7. 2020;7:ofaa375.

12. Deshwal R, Qureshi MI, Singh R. Clinical and laboratory profile of dengue fever. J Assoc Physicians India 2015;63:3032.

13. Chaloemwong J, Tantiworawit A, Rattanathammethee T, dkk. Useful clinical features and hematological parameters for the diagnosis of dengue infection in patients with acute febrile illness: a retrospective study. BMC Hematol 2018;18:20.

14. Huang C, Wang Y, Li X, dkk. Clinical features of patients infected with 2019 novel coronavirus in Wuhan. China. Lancet Lond Engl 2020;395:497-506.

15. Pan L, Mu M, Yang P, dkk. Clinical characteristics of Covid-19 patients with digestive symptoms in Hubei, 
China: a descriptive, cross-sectional, multicenter study. Am J Gastroenterol 2020;115:766-773.

16. Wang $\mathrm{D}, \mathrm{Hu} \mathrm{B}, \mathrm{Hu} \mathrm{C}$, dkk. Clinical characteristics of 138 hospitalized patients with 2019 novel coronavirus-infected pneumonia in Wuhan, China. JAMA 2020;323:1061-9.

17. Nimmannitya S, Halstead SB, Cohen SN, Margiotta MR. Dengue and chikungunya virus infection in man in Thailand, 1962-1964. I. Observations on hospitalized patients with hemorrhagic fever. Am J Trop Med Hyg 1969;18:954-71.

18. Mohamed NA, El-Raoof EA, Ibraheem HA. Respiratory manifestations of dengue fever in Taiz-Yemen. Egypt J Chest Dis Tuberc 2013;62:319-23.

19. Kulkarni V, Koppad B, Shetty MU. Profile of serum transaminases in patients with dengue infection in a tertiary care hospital. Int J Contemp Pediatr 2017;5:23.

20. Samanta J, Sharma V. Dengue and its effects on liver. World J Clin Cases 2015;3:125.

21. J B, Balasubramaniyan S, Paari N. Study of serum aminotransfersase levels in dengue fever and its correlation. J Med Sci Clin Res 2019;7:36-41.

22. Recalcati S. Cutaneous manifestations in COVID-19: a first perspective. J Eur Acad Dermatol Venereol 2020;34:e212-e3.

23. Solanke VN, Karmarkar MG, Mehta PR. Early dengue diagnosis: role of rapid NS1 antigen, NS1 early ELISA, and PCR assay. Trop J Med Res 2015;18:95-9.

24. La Marca A, Capuzzo M, Paglia T, Roli L, Trenti T, Nelson SM. Testing for SARS-CoV-2 (COVID-19): a systematic review and clinical guide to molecular and serological in-vitro diagnostic assays. Reprod Biomed Online 2020;41:483-99.

25. Verduyn M, Allou N, Gazaille V, dkk. Co-infection of dengue and COVID-19: A case report. PLoS Negl Trop Dis 2020;14:0008476.

26. Wu D, Lu J, Liu Q, Ma X, He W. To alert coinfection of COVID-19 and dengue virus in developing countries in the dengue-endemic area. Infect Control Hosp Epidemiol 2020;41:1482. 